\title{
The DevelopingOf Electronic Teaching Media and Programming Using Printed Circuit Board Solventing
}

\author{
Rahmat Hidayat $^{1}$, Ing. Reza Setiawan ${ }^{2}$, Vera Pangni Fahriani ${ }^{3}$ \\ Enjang Ahmad Juanda ${ }^{4}$,Rusman ${ }^{5}$ \\ ${ }^{1}$ Teknik Elektro, Fakultas Teknik, Universitas Singaperbangsa Karawang, Indonesia \\ ${ }^{2}$ Teknik Mesin, Fakultas Teknik, Universitas Singaperbangsa Karawang, Indonesia \\ ${ }^{3}$ Teknik Kimia, Fakultas Teknik, Universitas Singaperbangsa Karawang, Indonesia \\ ${ }^{4}$ Teknik Elektro, Fakultas Teknik, Universitas Pendidikan Indonesia, Bandung, Indonesia \\ ${ }^{5}$ Pengembangan Kurikulum, FIP, Universitas Pendidikan Indonesia, Bandung, Indonesia
}

Corresponding Author:

Email:rahmat.hidayat@staff.unsika.ac.id

\begin{abstract}
Karawang is one of the regency in West Java having many industrial area in Indonesia.One of the industrial field is electronic industry. This condition gives a chance to the graduatees of vocational High School students, especially electro major study, to gain an occupation and develop the entrepeneurship in the field of electronic appliances industry in Karawang. This research uses the methods of "rancang bangun". Sequencely, the method is a neccesity of identification needed. Then, this neccessity is analysed to obtain the specifically component. Furthermore, it is conducted soft and hard applicance design, making and testing. The result working from PCB based on the direction from a microcontroller Atmega 8 which have to control the servo motor spin and calcuyate the process timing device work. Before the program is undergone, the user have to reset the timer process solventing on the menu that can be set through LCD display. After the program is undergone, so the device will be working as the well made program.Timer will be working as fast as possible after being pressed the "run" button. When the solventing has achieved the setting value or mark, so the microcontroller will direct the step timer motor to stop working on and the buzzer will stop ringing until the reset button pressed or power bottom turning down.
\end{abstract}

Keywords: Karawang, Industry, Electronic, $P C B$.

\section{INTRODUCTION}

Industrial world is one of a triggering national economy. The Industry is spread out in various regions in Indonesia which laying on Java Island, Borneo, Sumatera, Sulawesi and Papua. Beside, The Industry in indonesia have varieties like eklectronics, otomotive, mining industry and the agricultural industry. One of the region which has many industries is Karawang. Industry in Karawang is really various, and one of them is electronic industry. The existence of industry must need a technology and technlogy of appliances or a device to ease the occupation in industry. 
The development of technology in this modern era always give an effect towards the appearance of new products which give many easiness towards human being. Industry has been developed along many discoveries and fasten the production process in it. The manufacture devices from conventional models has changed into portable and programmable based on computer and microcontroller

Besides, the educational world is one of the way to enhance the human resources development. In another hand, this industrial world is also one of the supporting national economy.

The blended of the educational and industrial world are able to make an advance to the nationwide by coordinating and triggering each other(link and match). One of the education focussed into the occupation world os vocational high school or Sekolah Menengah Kejuruan( SMK).

Karawang is one of the regency in West java which have Vocational high school and many industry in Indonesia.One of them is electronic industry. Beside that, data from Secondary education and non formal Board shows there are the increasing number of vocational high school anually.

The existence of a school must need the technology of teaching media such as the devices or the tools to increase hard and soft skills of the students in vocational high school. The development of technology and teaching media in this modern era are in line in giving the effect of new teaching media of the existence in the appearance of technology products.

The model of teaching media technology from the conventional ones( manual) has been changed to the portable and programmable based on computer/ (computer based) and microcontroller( automatics).

In making the design of electronics application is needed the medium called Printed Circuit Board (PCB) to set the electronics components. PCB is one of the thing or tool used to create an electronics circuit. All electronics products use this material to design a system in order to get it as its function. The process of making PCB is really easy and can be made by those who could master the technique of electronics. This step is called as "etching or solventing PCB". The pelarutan process of PCB is entering the PCB materials which has been depicted by lay out into the chemical Secondary liquids, then, moved into the copper is out.

One of the obstacle in the making process of $\mathrm{PCB}$ is, there is no teaching media like a solventing portable device that can help the process of pelarutan in Vocational High School. To make a liquid of PCB in a big scale(industrial scale) is really not effective, if it is conducted handmade or manually because making it would be more tiring. Furthermore, the unconstant velocity or speed can make the liquids PCB prolong this process and wasting the time. In making the aim comes true, it is needed a teaching media of PCB in giving a hand in the effective portable PCB process. 

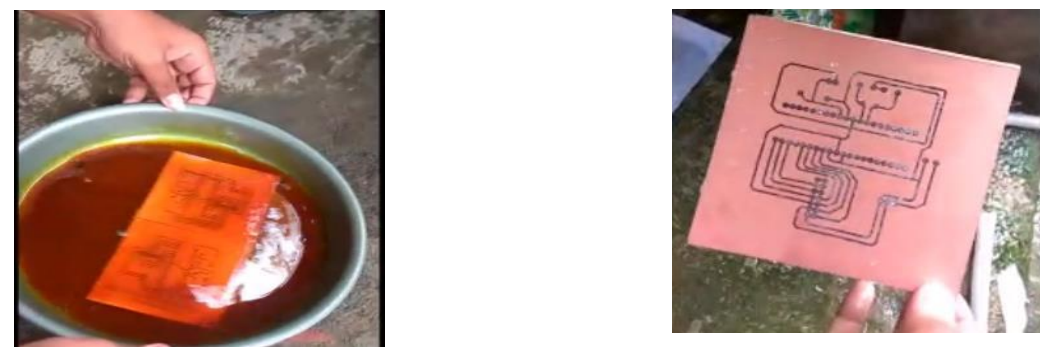

Picture 1. The process of Manual Making through PCB

On coherence with it, it is needed the existence of electronics teaching media and programming using the portable of Pelarut PCB(Printed Circuit Board) in Vocational High School (SMK) in Karawang Regency as a supporting electronics teaching media in electro technique, industrial electro, and audio video technique major studies.

Electronics Teaching Media and Programming using the portable solventing device PCB( Printed Circuit Board) needed to ease the electronics appliances teaching and programming enable the students to master the materials, develop the quality of vocational high school industrial based and gain the potency of electronics appliance and programming through the portable PCB oelarut device that has been design its outline.

The aim of the research, The Development of Electronics Teaching Media and Programming using PCB( Printed Circuit Board) in vocational high school(SMK) in Karawang regency are to build and apply:

a. Media software of electronics teaching and programming using PCB pelarut device in Vocational High School in Karawang regency,

b. Hardware for electronics teaching media unit and programming using the PCB pelarut device in vocational high school in Karawang regency,

c. Understanding the prochedure.

\section{METHODS}

The research methodology used is 'design' methods. The design is conducted to gain the "second to none" design and the portable prochedure pelarut PCB device in Karawang regency. The research process planning is started in the field of problem study.

The next step is the device design by the concept of theory based. The making process is begun from the necessity analysis which would be used to create automatic PCB pelarut device. After making necessity analysis, the further is collecting the material and product making. Product making is needed a completion through the product's revision. After the product is tested and, then, fit and proper test, so that it could be continuing in mass production.

The data collecting technique conducted is a literature and field notes try to the electronics teaching media technology and programming by using the 
PCB pelarut device via Focus Group Discussion(FGD) in vocational high school in electronic, informatics and electricity in Karawang regency

\section{RESULT AND DISCUSSION}

\section{The Research Result}

The PCB pelarutan process is entering the PCB material which has been depicted by "lay out" into the liquids of PCB pelarut that is Feri Klorida ( $\mathrm{FeCl} 3)$ then move into the residu of Chrom? tembaga. The potency of vocational high school quality will be increasing and attain the skills of electronics appliance and programming through the teaching media portable PCB solventing device.

Based on the research from the co- operation among the University entitled "The Development of Electronics Teaching Media and Programming Using PCB pelarut Device in the Vocational High School(SMK) in Karawang regency" is a product of precise technology that has been tested in electronics laboratory and EMC B4T(Balai Besar Bahan dan Barang Teknik) Indonesian Republic Industrial Ministry which have been prooved through certificate report. Below is the result of testing product of electronics Teaching media and Programming using PCB(Printed Circuit Board) solventing device.

Tabel 1. The Saving of Power Input

\begin{tabular}{|c|c|c|}
\hline Tools Variety & $\begin{array}{c}\text { The Rated Power Input } \\
\text { (W) }\end{array}$ & Deviant \\
\hline all applyances & $\leq 25$ & $+20 \%$ \\
\hline $\begin{array}{l}\text { Heating Device and } \\
\text { Compound Device }\end{array}$ & $>25$ dan $\leq 200$ & $+5 \%$ atau $20 \mathrm{~W}$ \\
\cline { 2 - 3 } & $>200$ & $+20 \%$ \\
\hline $\begin{array}{l}\text { Motoric Cooperated } \\
\text { Device }\end{array}$ & $>25$ dan $\leq 300$ & $+15 \%$ atau $60 \mathrm{~W}$ \\
\cline { 2 - 3 } & $>300$ & \\
\hline
\end{tabular}

Table 2 Current Deviant

\begin{tabular}{|l|c|c|}
\hline \multicolumn{1}{|c|}{ Tools Variety } & Rated Current (Amp) & Deviant \\
\hline All Applyances & $<0,2$ & $+20 \%$ \\
\hline $\begin{array}{l}\text { Heating Device and } \\
\text { Compound Device }\end{array}$ & $>0,2$ dan $\leq 1,0$ & $\pm 10 \%$ \\
\cline { 2 - 3 } & $>1,0$ & $+5 \%$ atau $0,1 \mathrm{~A}$ \\
\hline $\begin{array}{l}\text { Motoric } \\
\text { Cooperated Device }\end{array}$ & $>0,2$ dan $\leq 1,5$ & $+20 \%$ \\
\cline { 2 - 3 } & $>1,5$ & $+15 \%$ atau $0,3 \mathrm{~A}$ \\
\hline
\end{tabular}

Based on the result of power and current above, that the example can be linked into the AC Source to obtain the understanding about the power and " rated current". The output voltage out according to rated voltage. The power and current measured are noted at the stabil condition reached. On behalf of the customer demand, the testing of this sample is conducted at every angle with the maximum $(1,4 \mathrm{Kg})$. 
Furthermore, in the power test and this input, there is a deviant power input started from the kinds of tools, power input of pengenal(W) and deviant.

Besides, the result of research portable PCB solventing device supporting electronics appliances industry in Karawang regency use the method of design/ building design. Sequencely, the method is a neccesity of identification needed. Later, the neccesity is analyzed to obtain the component specifically. Further, it is conducted the design of hardware and software, the making process and testing.

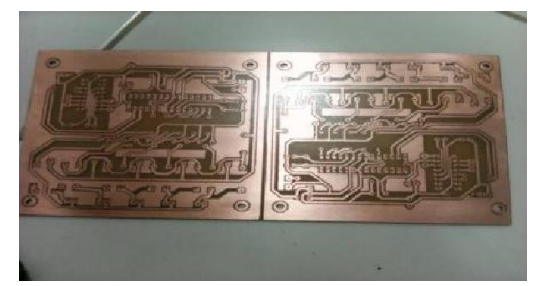

Picture 2. The result of PCB after Solventing

\section{The Steps of Making Device}

The steps of making a device in this LPPM research consist from outlining the box making, solventing PCB, setting the component into PCB.

The Making Of Outlining Box

The Making process of outlining the box is made in the repair shop by using the available applicances. The boxes are used to set the outline and the setting place of solvent tube sized $24 \mathrm{~cm} \times 32 \mathrm{~cm}$. The process of box making is conducted started from the alumunium cutting, folding, and drilling. From the prior size planning has been gained as the result shape of the box below.

Noted:

Sakelar $=$ Button

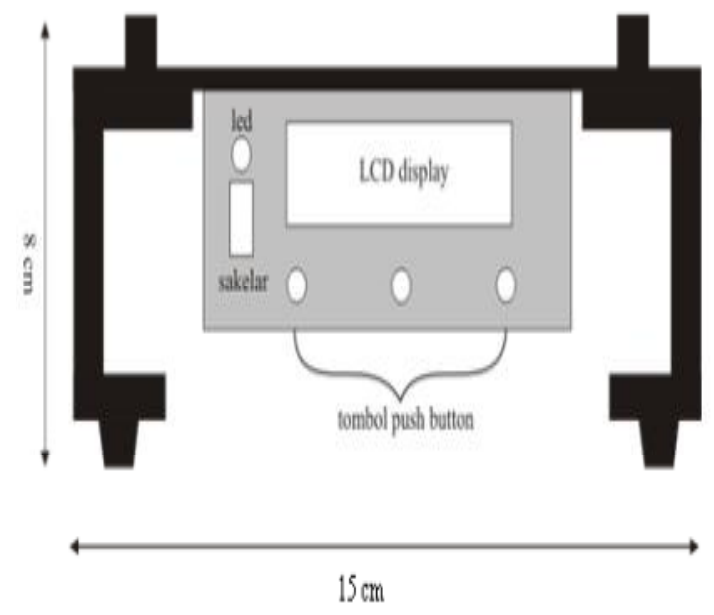

Picture 3. Front box.

http://ijstm.inarah.co.id 


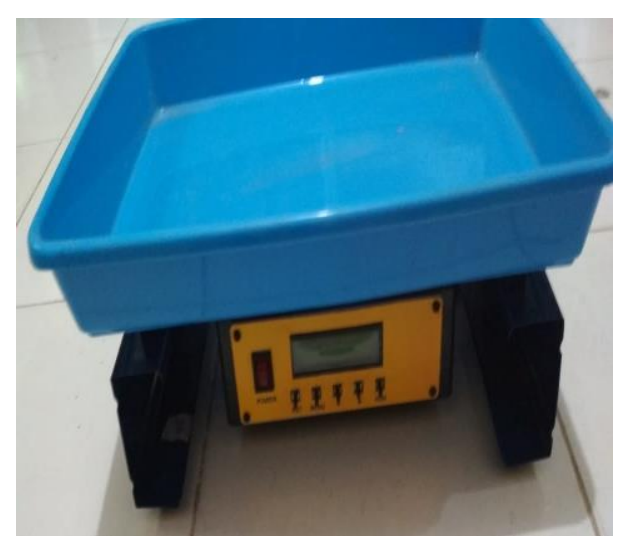

Picture 4. The depiction of electronics teaching media and programming using the PCB solvent device

1. The Making of PCB

a. The making of PCB lay out.

First step of making PCB is drawing or depicting outlines lay out by software proteus.

b.

Duplicate or copying the PCB

After the lay out getting finished, the next step is duplicate the lay out into the neutral PCB. The process of duplicate is made by these several ways, they are:

1) Print out the layout on the glossy paper.

2) The layout design which has been printed out on the glossy is duplicated to PCB by being ironed at least ten minutes.

c. After the layout drawing clings on PCB so that remove the paper by water until it is cleaned. Solventing and Drilling the PCB.

The next step is solventing PCB by the liquids of Feri Chloride until the outline path is made. Then, after the path is made conveying PCB from the liquids of Feri Chloride and cleanse it with water. After getting clean, PCB is drilled based on the points.

\section{Component Setting}

The last step is setting all the components available in the outline by the sequence below, they are:

a.

b.

c.

d.
Preparing the component in need.

Setting the components from the early tiny size first.

Schrewdrivering the foot of the components until all the components set.

Testing the outline whether it is able or not to work well or not yet. 


\section{Flowchart Program}

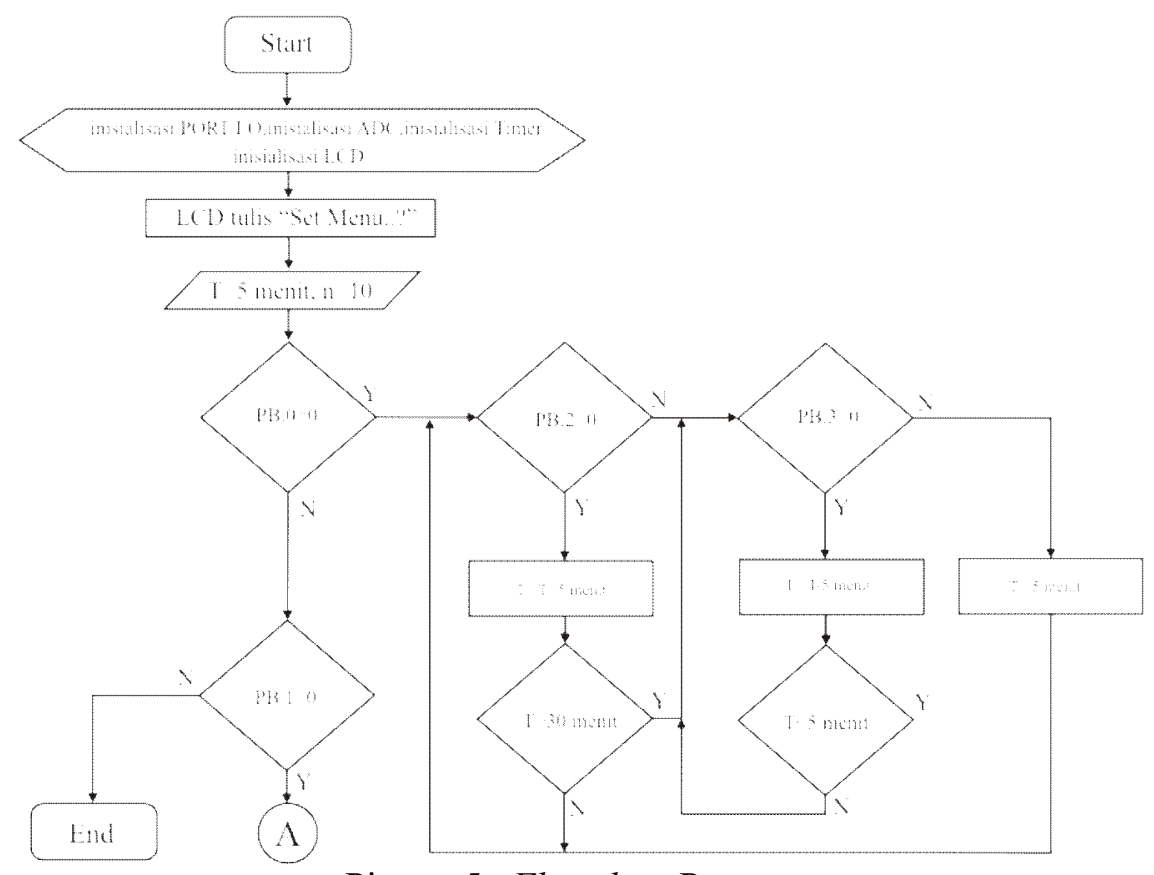

Picture 5. Flowchart Program

The Program in the electronics teaching medium and programming using the PCB solventing device is made with the $\mathrm{C}$ language, Phyton and use arduino IDE software and CodeVision AVR. To carry out the program are used several facilities including in microcontroller Atmega 8 such as the Timer, ADC and LCD. The arrangements of the programs contains the menu of setting program, servo cycling, ADC value control, and timer calculation.

\section{DISCUSSION}

Based on the research and work in the electronics teaching media and programming using PCB solventing device is gained the conclusion that the outline can work well based on its function. According to the measurement from the parts of the system, there are several different result measurements of what does not attained in theory or component datasheet. But the difference do not cause the disorder of the appliances. This difference occurs because there are some kinds of factors such as the value of component which is not always precise or sharp according to its label, the tolerance of component value from manufacture, wrong measurements and the condition of unwellness of well standardize device.

1. The Analysis of power supply outlining.

At the measurement of power supply, there is a decreasing result of rate voltage output in regulator 7805 , that is, $4,94 \mathrm{~V}$. In regulator 7809 is $8,93 \mathrm{~V}$, 
meanwhile in 7812 is $12,10 \mathrm{~V}$. In those output tegangan does not affect work system. The things affect the decreasing TEGANGAN mark/ value are:

a. The existence of component tolerance.

b. Measurement disorder.

c. The condition of unwell measurement appliance

2. The analysis of solventing timing.

In the solventing timing measurement is gained the data that the tools can conduct the PCB solventing process by timing appropriate to PCB size which would be solventing. In this solventing timing is managed by microcontroler using the timer facility that is include in ATmega 8.

\section{The analysis of Motor Servo Spinning.}

From the testing device gained the data that servo can have a good function, that is, can spin as planned. Based on PWM output result picture is produced microcontroller achieved the data as the servo is moving forward(clock-wise), the amount of pulse measured is $1,8 \mathrm{Ms}$. When the servo went back(counterclockwise), the amount of pulse measured is $1 \mathrm{Ms}$. The amount of pulse measured based on the theory, which is, servo, would move forward if it is delivered the pulse less than 1,5 Ms. Meanwhile it would not go back if it is delivered the pulse less than 1,5 Ms.

\section{Buzzerif Analysis}

Buzzer in this outline can work well. Buzzer is sounding when solventing timing is out, so it has been marked out of the time.

\section{LCD Performing Analysis.}

When the LCD solventing timing setting procceed could show the characters called by the program. This signs that the program performing LCD is being well functioned. When the process of characters performing in LCD is having a blink of an eye, it is because of the impact of delay given in the performing characters. In this program, delay which given is $3 \mathrm{Ms}$.

\section{Analysis Program.}

The software making program with the Arduino IDE and CVAVR is able to work well based on the plan. It could undergo all the direction made in $\mathrm{C}$ Language Code and Phyton, that has been entered at microcontroller in A. This Program making with software Arduino IDE and CVAVR could work well based on the planning. This program is designed by the flowchart diagram as made previously.

\section{CONCLUSION}

From the research can be attained the conclusion as followed:

1. Electronic teaching media and programming using the PCB solventing device can be creating by using microcontroller ATMega 8 minimum system which is combined by several supporting instruments such as mechanics, servo motor, and LCD http://ijstm.inarah.co.id 
display.In another hand, PCB solventing device could work well to make a solventing single layer PCB. This PCB solventing device also can be used as the electronics teaching media and programming in Vocational High School(SMK) in Karawang.

2. Electronics teaching media and programming using the PCB solventing device can procceed the controlling servo motor and giving the PWM pulse that could be raising from the microcontroller in arduino. Besides, the timer management in the process of PCB solventing device is conducted by setting the mark TCNT1H and TCNT1L on the TCNT1L at register timerl in microcontroller in arduino. Electronics teaching and programming using PCB solventing device is also as the development skills creativity in designing the electronics appliances and programming using this microcontrol in vocational high school(SMK).

\section{ACKNOWLEDGMENTS}

We praise to alloh and thanks for the triggering fund for the cooperation research among universities or colleges(PKPT/ Penelitian Kerjasama Antar Perguruan Tinggi), to the Research Directorate and Community Devotion(DRPM/ Direktorat Riset dan Pengabdian Masyarakat) year 2020, General Directorate Research Strengthening and the Development from Research Ministry and Technology/ Research Board and national Inovation.

\section{REFERENCES}

[1] Andrianto, Heri.(2008). Microcontroller Programming AT Mega 16 using AVRCode Vision . Bandung: Informatika

[2] Ary Heryanto, M and Adi P. Wisnu (2008). C Language Programming for Atmega Microcontroller 8535.. Yogyakarta: Andi.

[3] Budiharto, Widodo and Rizal, Gamayel (2007). 12 Microcontroller Project for begginer. Jakarta: Elex Media Komputindo.

[4] Setiawan, Iwan ST.MT, (2006). MicrocontroleofTutorial AVR, http://iwan@elektro.ft.undip.ac.id, 3 Juni 2019.

[5] Rif Cool,(2009). Activating Servo Motor by basin, http://rif_cool@yahoo.com, 3 Juni 2019. 